\title{
STRUCTURAL AND ULTRASTRUCTURAL STUDY OF CAPSICUM ANNUUM LEAVES AFTER TREATMENT WITH UNCARIA TOMENTOSA BARK EXTRACTS
}

\author{
TERESA TYKARSKA ${ }^{1}$, KRZYSZTOF GULEWICZ $^{2}$, AliCJA ZOBEL $^{3}$, \\ Julita AugustynOwicZ ${ }^{1}$, KATARZYNA ŻUROWSKA ${ }^{4}$, MieCZYSŁaW KuRAŚ ${ }^{1}$ \\ ${ }^{1}$ Department of Plant Morphogenesis, Warsaw University \\ Miecznikowa 1, 02-096 Warsaw, Poland \\ ${ }^{2}$ Laboratory of Phytochemistry \\ Institute of Bioorganic Chemistry PAN \\ Z. Noskowskiego 12/14, 61-704 Poznan, Poland \\ 3 Trent University, Peterborough \\ Ontario, K9J 7B8 Canada \\ ${ }^{4}$ A-Z Medica \\ Czyżewskiego 6/1 A, 81-706 Sopot, Poland
}

(Received: September 19, 2002. Accepted: April 4, 2003)

\begin{abstract}
The influence of an Uncaria tomentosa extract on the development of Capsicum plants grown in green-house conditions was examined. The effect of the treatment was investigated with microscopic techniques (light and electron microscope) in leaves from three levels of control plants and plants after treatment with the extract added to the soil in doses of 0.4 and $16 \mathrm{mg} / \mathrm{ml}$ (200 ml per pot/plant). In control leaves, changes typical of the subsequent phases of normal development were observed: nuclear chromatin became slightly condensed, plastoglobuli of chloroplasts increased in number and size, intragranal thylakoids were somewhat dilatated. In addition to such commonly occurring changes, some symptoms typical of pepper were observed in the ontogenesis of the examined plant: an increased number of spherical electron-dense deposits in vacuoles, an increased number of peroxisomes, the occurrence of numerous paracrystalline structures in chloroplasts of mature leaves, and, starting in mature leaves, expulsion of plastoglobuli from chloroplasts.

After the treatment, most of those changes, leading to ageing, occurred much earlier and were more distinct. Chloroplasts, already in the youngest examined leaves, showed dilatation of intergranal thylakoids, which intensified with aging of the leaves and degradation of grana in the oldest leaves. Starch grains decreased in size and number and plastoglobuli became large. Vesiculation of ground cytoplasm in all leaves was stronger than in the control. No paracrystalline structures in chloroplasts or expulsion of plastoglobuli were observed. Another unusual phenomenon was the disappearance of spherical electron-dense deposits in the central vacuoles of cells.

Those observations suggested that $U$. tomentosa extract enhanced the natural ontogenesis of Capsicum annuum leaves, by accelerating and enhancing the typical characteristics of ageing, and, additionally, it changed the structure and physiology of cells.
\end{abstract}

KEY WORDS: Capsicum leaves, extract of Uncaria tomentosa, cytostatical action, ultrastructure.

\section{INTRODUCTION}

Uncaria tomentosa (Willdenow ex Roemer and Shultes) DC., from Rubiacae family, is a liana growing wildly in the jungles of South and Central America. It is known as „vilcacora”, „una de gato" or „cat's claw” and it stirs up the interest of investigators representing numerous fields, from physicians through pharmacologists to economists. Preparations obtained from pulverised bark, leaves or roots of this plant have been used for a long time in folk medici- ne by Amazonian Indians for the treatment of various diseases, including cancer, arthritis or infectious diseases (Keplinger 1982).

The most important group of biologically active substances occurring in $U$. tomentosa is a group of alkaloids, which are important therapeutic compounds of plant origin. In comparison to other plant species, alkaloids are extremely abundant in the Uncaria genus (Laus 1997). In addition to alkaloids, $U$. tomentosa extract contains other pharmacologically active compounds, such as proantocya- 
nids (Motenegro de Matta 1976, many sterols Senatore 1989), quinovic acid glycosides and numerous triterpenes (Aquino 1977).

Up to date, a large number of research projects aimed at testing the influence of an $U$. tomentosa bark extract on animal cells and organisms have been carried out. The results of those tests have proven that the bark extract components act directly and indirectly on animal cells, causing different reactions. For example, it has been found (Sheng 1998), that water extract from the bark inhibited proliferation of human cancer cells HL60 grown in in vitro conditions and induced their apoptosis. It has been observed that, in spite of its strong toxic properties with respect to cancer cells, the extract was safe for healthy cells, which remained unchanged even under the treatment with its large amounts. (Sheng 2000). Besides, strong cytoprotective influence of the extract on cells previously treated with various apoptosisinducing substances has been shown by Sandoval-Chacon (2000). Some authors have proven the anti-inflammatory (Sandoval-Chancon 1998, Bednarek 2001), anti-viral (Keplinger 1999) and contraceptive (Salazar 1998) properties of the extract. On the other hand, numerous studies have indicated immunostimulating activity of the extract. In general, various studies yielded a wide range of effects produced by $U$. tomentosa extract, however the mechanisms underlying these effects have not yet been identified. Unfortunately, all the works have been fragmentary and they have not provided a full description of the effects or therapeutic properties of the studied extract.

Thus, Uncaria tomentosa remains a mysterious plant, arousing both hopes and fears, as well as a lot of controversies, which mainly result from insufficient knowledge of the extract effects. Their cytological examinations, although very important, are few, and there are no analyses of their impact on ultrastructure of cells, especially of cancer lines cultured in vitro and in model plant systems. However, none of previously used plant models of biological activity is ideal. This results in necessity of examining Uncaria tomentosa extracts in a broader range of tests and gathering information on their biological properties. In connection with this, our team undertook a comprehensive cytological research into the influence of the extract on meristematic cells in a model plant system of Allium, with the idea to further test it on human cancer cells.

In this regard, we also examined the influence of $U$.tomentosa bark extracts on Capsicum annuum plants, and in particular on the ultrastructure of their leaf cells, which in a relatively short time progress from the phase of initiation, through physiological maturity, to aging and apoptic death. This is quite a different plant test as it takes into account the entire, specific ontogenetic development cycle. Capsicum was chosen as the model, for, apart from its usability, it showed the highest allelopathic sensitivity to Uncaria tomentosa bark extracts, which had been shown in our earlier investigations (Gulewicz et al. 2002), carried out in greenhouse conditions. Additionally, it underwent the whole developmental cycle in controlled conditions, in relatively short time, and it showed marked activity in productions of secondary metabolites. The use of Capsicum test, apart from other plant tests (such as Tradescantia, Zea or Vicia) may supplement them in early investigations of biological activity of plant preparations, including potential anti-cancer factors, such as Uncaria tomentosa bark extracts.

We expect that the results of these investigations will provide additional information on the biological activity of $U$. tomentosa extracts, which may facilitate their proper evaluation and the determination of their prospective applications. This work is also a continuation of our earlier research (Gulewicz et al. 2002) of the influence of the extract on the developmental morphological changes, now supplemented with an analysis of ultrastructural changes.

\section{MATERIAL AND METHODS}

As material for our experiments, we used pepper plants (Capsicum annuum L.) var. Koźlak, cultivated in pots with garden soil kept in green house, in natural light and temperature conditions. After three months of culture, just before blossoming, three groups (each consisting of 6 identical plants) were selected, the first of which was treated with $200 \mathrm{ml}$ of Uncaria tomentosa bark extract (Laborations Induquinica Lima, Peru) at the concentration of $0.4 \mathrm{mg} / \mathrm{ml}$, the second group was treated with the same amount of extract at the concentration of $1.6 \mathrm{mg} / \mathrm{ml}$, and the third group was treated with $200 \mathrm{ml}$ of distilled water (control group). After three weeks from the treatment of plants with the extract, when the differences in the appearance of the particular groups of plants were most distinct (control plants were bigger and intensly green, while treated plants were smaller and yellowish, according to the extract concentration), samples were fixed for microscopic tests.

Figs 1-7. Cross-section of an old control leaf (Fig. 1) and a leaf after treatment with $U$. tomentosa extract (Fig. 2). Semi-thin sections, stained with $1 \%$ toluidin blue, observed in a light microscope. Bars $=100 \mu \mathrm{m}$. Ultrastructure of a young control leaf (Figs 3-7). Ultrathin sections, contrasted according to Reynolds. All other electronograms were made with this technique.

Fig. 1. A control leaf: large, dark chloroplasts at cell borders; cells filled with gleaming deposits in the middle layer of mesophyll (white and black arrows).

Fig. 2. A leaf after treatment with the extract of U. tomentosa bark: slightly deformed and strongly vacuolated cells (arrows), vacuoles without gleaming deposits; chloroplasts are fewer, smaller and much lighter than in the control.

Fig. 3. Cells of upper epidermis and palisade parenchyma: cytoplasm containing large chloroplasts (Ch) with numerous starch grains (S); spherical electron-dense deposits (sd) in vacuoles. Bar $=3 \mu \mathrm{m}$

Fig. 4. A fragment of a spongy parenchyma cell: nucleus (N) with small fragments of condensed chromatin (arrows) and nucleolus (Nu); chloroplasts containing plastoglobuli (pg) with dark spots at their borders; mitochondria (M) with dense matrix and numerous dark cristae; cytoplasm containing vesicles (v) with electron-dense deposits (arrows). Bar $=1$ um.

Fig. 5. A fragment of a spongy parenchyma cell: the vacuole containing spherical electron-dense deposit (sd), polyvesicular bodies (mv) both under the tonoplast $(\mathrm{t})$ and in the central vacuole; the chloroplast containing very small osmophil plastoglobuli $(\mathrm{pg})$. Bar $=1 \mu \mathrm{m}$.

Fig. 6. Palisade parenchyma: chloroplasts with high piles of grana (g), numerous starch grains and small dark plastoglobuli. Among them, a complex polyvesicular structure $(\mathrm{mv})$ is visible, invaginating into the central vacuole $(\mathrm{V})$. Bar $=1 \mu \mathrm{m}$.

Fig. 7. A fragment of palisade parenchyma: peroxisom $(\mathrm{Pe})$ with a typical electron-dense paracrystalline core. $\mathrm{Bar}=1 \mu \mathrm{m}$. 

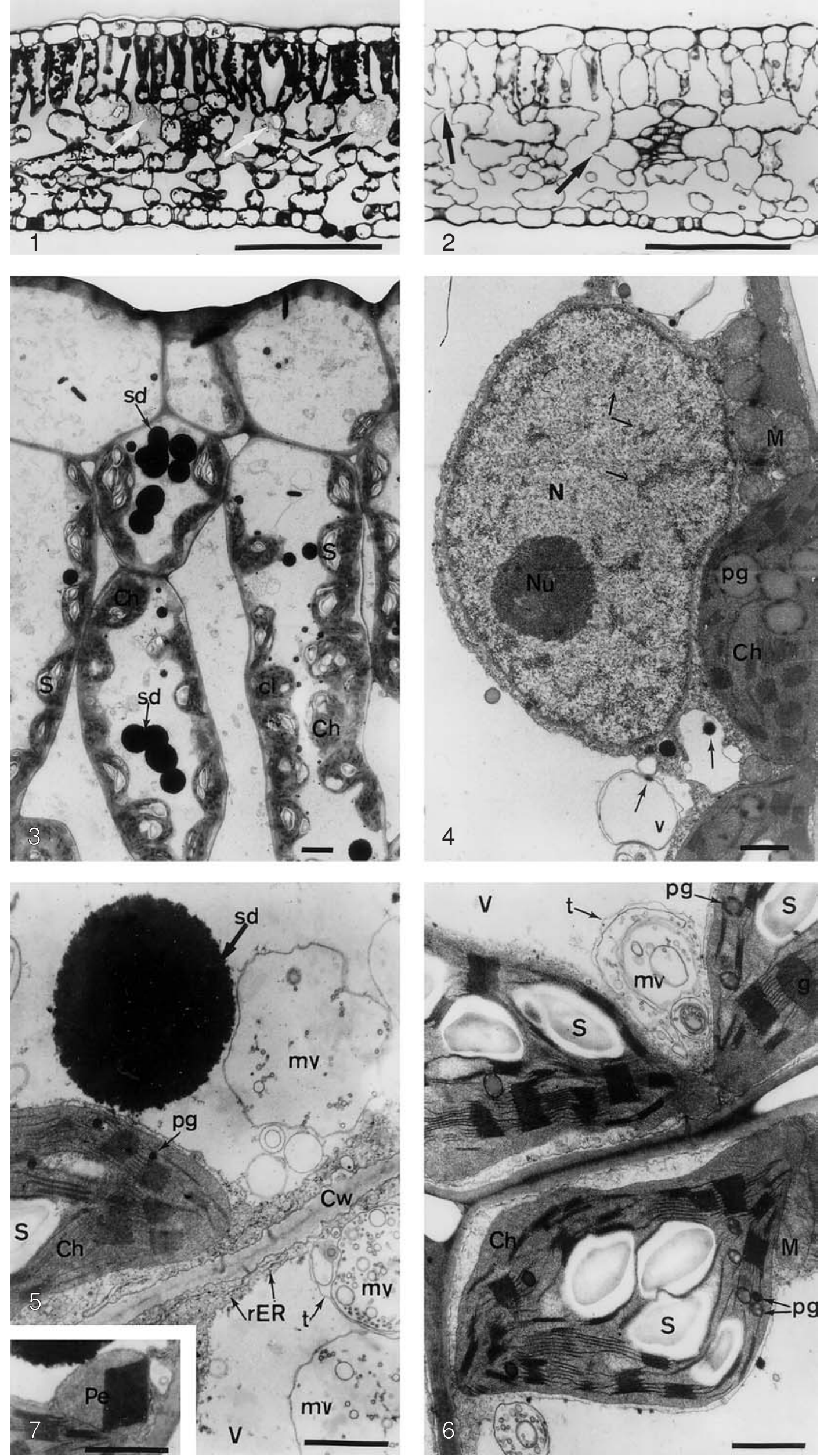
From each plant, leaves from three levels were collected: the upper level (the third leaf from the top), the middle level (the tenth leaf from the top) and the bottom level (the lowest leaf in the plant - usually the sixteenth). Hereinafter they are referred to as young, mature and old leaves, respectively. Squares of side length equal $\pm 1 \mathrm{~mm}$ were cut from the middle part of the leaf blade (between the midnerve and the 2nd and 3rd lateral nerve) and fixed in $2.5 \%$ glutaraldehyde at $\mathrm{pH} 7.2(0.1 \mathrm{M}$ cacodylate buffer $)$ for 2 hours, and then postfixed in $1 \% \mathrm{OsO}_{4}$ for 12 hours. After desiccation in ethanol, the material was embedded, through propylene oxide, in Epon/Spurr mixture. The embedded leaves were cutted with LKB ultramicrotome. Semi-thin sections, about $0.5 \mu \mathrm{m}$ thick, were stained with $1 \%$ toluidine blue in $1 \%$ borax, observed in a NU ZEISS light microscope and photographed by the standard method with a photographic camera. Ultra-thin sections, 60-90 nm thick, were contrasted with uranyl acetate and lead citrate according to Reynolds (1963); observations and electronograms were made in a JEOL JEM 100C transmission electron microscope.

\section{RESULTS}

Structure of control and treated leaves

The pepper plants treated with the extract were retarded in growth. Flowering and fruiting were accelerated and young fruits fell sooner. The leaves were a bit smaller in comparison with the control and yellow edges appeared on the oldest treated leaves, whereas only small parts at the very edge of the oldest control leaves were affected.

In semi-thin cross-sections, observed in light microscope (Fig. 1), leaves of control plants had a typical structure, composed of palisade parenchyma consisting of one layer of cells, a 3-4 cell-thick spongy parenchyma and single vesicular tissue bundles. The layer of the spongy parenchyma adjacent to the palisade parenchyma consisted of larger cells, adjacent to one another and filled with opalescent crystalline deposits (Fig. 1 - arrows). All cells of those leaves had a large central vacuole, and the thin parietal layer of cytoplasm contained cell organelles, among which chloroplasts were best visible, making the cells, especially those of the palisade parenchyma, dark green.
The aforedescribed basic structure was generally typical of leaves of all the control and treated plants. From the ontogenetic point of view, the difference between them consisted in an increased vacuolation of cells in older leaves. Moreover, the treated leaves (Fig. 2) distinctly differed from the respective control leaves in slightly thinner leaf blades, lighter color of cells, probably resulting not only from stronger vacuolation of cells, but also from the decreased number and size and a weaker color of chloroplasts. Mesophyll cells of the treated plants were slightly deformed (Fig. 2 - arrows) and did not contain glossy opalescent deposits.

\section{The ultrastructure of control leaves Young leaf}

In the ultrastructural picture of mesophyll cells of young leaves, very large vacuoles prevailed, located in the central part of cells and containing numerous electron-dense spherical deposits (Figs 3, 5). The cytoplasm appeared as a layer adjacent to the cell wall, containing cell organelles (Fig. 3 ). Chloroplasts contained regularly built grana, parallel intergranal thylakoids and numerous large starch grains (Fig. $6)$. In the chloroplast matrix, scarce electron-grey plastoglobuli with dark borders were observed, usually small and containing peripheral granularities, or internal lucent spots (Figs 4, 6-arrows). The appearance of the remaining organelles was typical of metabolically active cells: a nucleus with slight condensation of chromatin and a nucleolus, indicating its high transcription activity (Fig. 4), oval mitochondria with dense matrix and dark cristae (Figs 4, 6); microbodies, mainly peroxisomes, with typical electron-dense large paracrystalline bodies (Fig. 7). Rough endoplasmic reticulum appeared as scarce short tubules, located parallel to the cell wall (Fig. 5). The cytoplasm often contained electron-lucent vesicles of different sizes, containing osmophil deposits (Fig. 4), single polyvesicular bodies (Fig. 5), or their conglomerations in concentric systems. Many of them, pressing the tonoplast, were invaginated into the central vacuole (Figs 5, 6-arrows) or were contained inside it (Fig. 5).

\section{Leaves in the later phase of ontogenesis}

Further development of leaves showed typical changes in their ultrastructure. Elevated vacuolation of mesophyll

\section{Figs 8-13. Ultrastructure of control plant cells: a mature leaf Fig. 8-10, an old leaf Fig. 11-13. Bars = $1 \mu$ m.}

Fig. 8. Palisade parenchyma: Chloroplasts with oblong electron-dense paracrystalline bodies (pc) (arrowheads mark the range of thylakoids in a chloroplast deformed by pc). In the bottom chloroplast, a plastoglobule (pg) is visible, pushing its border towards the vacuole (thick arrow); the central vacuole contains large osmophil spherical deposits (sd) and vesicular membrane-like structures (ms) (arrowheads), with small electron-dense deposits (d). A similar ms, enveloped with tonoplast ( $\mathrm{t}$ ), invaginates into the central vacuole.

Fig. 9. A fragment of the palisade parenchyma: a membrane-like structure (ms), invaginating into the central vacuole (v). The neighbouring cell contains electron-lucent vesicles (v) under the tonoplast (t), not invaginating into the vacuole; a large spherical deposit (sd) in the vacuole; the cytoplasm contains mitochondria and a peroxisome (pe) with a dissolving core.

Fig. 10. A fragment of spongy parenchyma: the cytoplasm contains concentrations of lucent vesicles (ms) with lucent and grey smaller vesicles (v) and osmophil deposits (d), a chloroplast (Ch) and a mitochondrion (M), a microbody (m), a dictyosome (D), separating a mass of very small vesicles (two thin arrows); the vacuole contains a spherical deposit (sd) and polyvesicular structures.

Fig. 11. A fragment of palisade parenchyma: the nucleus containing numerous fragments of condensed chromatin (arrows); chloroplasts with all-grey plastoglobuli (pg); the vacuole with numerous spherical deposits (sd) and an expelled plastoglobule with lucent bubbles (pg, arrow).

Fig. 12. A fragment of spongy parenchyma: the central vacuole surrounded with lots of connected vesicles (v), with black spherical deposits (sd) stuck among them. A plastoglobule (pg) with lucent bubbles (arrowhead) is visible at the border of the chloroplast.

Fig. 13. A fragment of spongy parenchyma: at the border of cytoplasm, merged vesicles (v) are visible with spherical deposits stuck among them. The deeper layer of cytoplasm contains many electron-lucent vesicles (v), lipid-like deposits (ls), a peroxisome (Pe) with a large core and a mitochondrion (M) with very dense matrix and dilated cristae; the chloroplast $(\mathrm{Ch})$ has slightly dilated granal thylakoids (thin arrows); a plastoglobule leaving the chloroplast (2 arrow head) is visible. 
cells, with a simultaneous marked increase in the number of spherical dark deposits, occurring in vacuoles (Figs 8, 13) was observed.

Cells of mature leaves contained fewer single polyvesicular bodies, but apparently more other membrane-like structures. Most often, these were concentrations of lucent vesicles and flattened ER structures (Fig. 9 - arrows), containing small osmophil deposits (probably the origins of large spherical deposits) (Figs 8, 10) and small (electronlucent or grey) vesicles (Figs 9, 10 - arrows). Such concentrations, surrounded with a common envelope, were located within the cytoplasm (Fig. 10 - arrowheads), often ad-
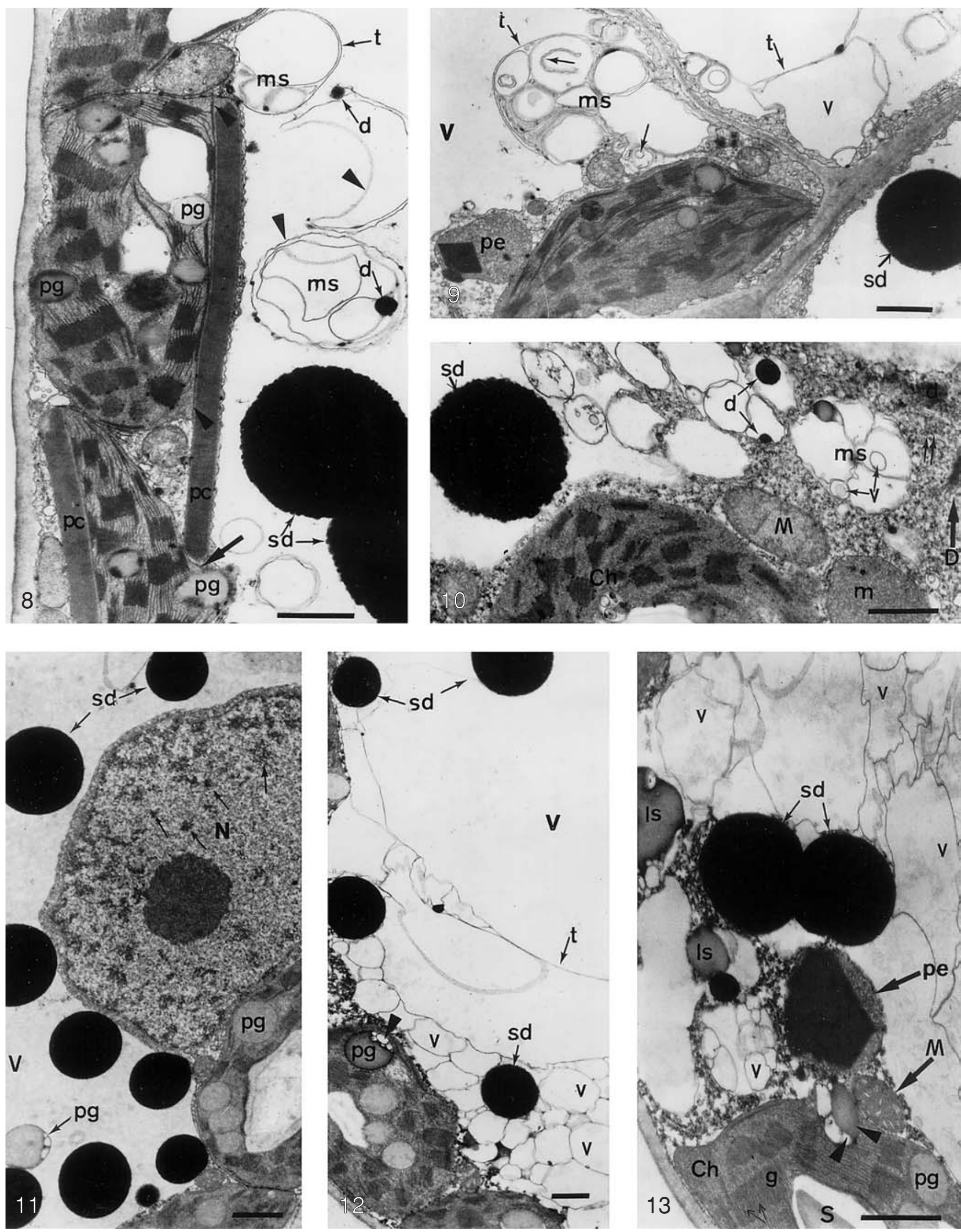
hering to the tonoplast, which usually caused their invagination into the central vacuole (Figs 8,9 t-arrow). In the oldest leaves, lucent vesicles usually gathered under the tonoplast, not invaginating into the central vacuole (Fig. 12). Large electron-dense spherical deposits, similar to those occurring in the central vacuole, were stuck among them. Chloroplasts contained smaller starch grains, but grana and intergranal thylakoids preserved a structure typical of the youngest leaves. In the oldest leaves, only slight dilatations of granal thylakoids were observed (Fig. 13). Plastoglobuli were larger and more electron-lucent than in the young leaves (Figs 8, 9). Starting from mature leaves, plastoglobuli, by pressing the envelope, were often expelled (usually together with accompanying electron-lucent vesicles) outside chloroplasts to the cytoplasm (Fig. 13 - arrowheads), or even to the central vacuole (Fig. 11 - arrow). We could not see what they were enveloped with after leaving the chloroplasts, but their border was always dark. Lipid-like structures observed in the cytoplasm of old leaves, which might originate from expelled plastoglobuli, had similar envelopes (Fig. 13).

Chloroplasts of mature leaves (only at this stage) very often contained long paracrystalline structures, located outside thylakoids (Fig. 8 - arrowheads), usually at the very border of chloroplasts, which drastically deformed their shape (Fig. 8). Mitochondria, still having dense matrix and numerous cristae, seemed very active. In the oldest leaves, their matrix was more condensed, and cristae were dilated and more lucent (Fig. 13). Similar to young leaves, chloroplasts and mitochondria were accompanied by peroxisoms (Figs. 9, 13). Their number increased in mature leaves. In the oldest leaves, there were fewer of them, but usually they contained a much larger paracrystalline core (Fig. 13).

In cells of those leaves, active dictyosomes were often observed, producing masses of small grey vesicles (Fig. 10, two-thin - thin arrows).

The structure of the nuclei was characterised by slightly stronger condensation of chromatin than in younger leaves (Fig. 11 - arrows).

\section{Ultrastructure after treatment with the extract} Influence of the $0.4 \mathrm{mg} / \mathrm{ml}$ concentration

The ultrastructural organisation of leaves showed visible changes already after the treatment with $U$. tomentosa bark extract in the lower concentration of $0.4 \mathrm{mg} / \mathrm{ml}$.

Spherical, electron-dense deposits in vacuoles disappeared. Regardless of the stage of leaf development, chloroplasts did not contain paracrystalline structures. Unlike in the control, plastoglobuli were not expelled from chloro- plasts. However, in chloroplasts of old leaves, the size and number of plastoglobuli increased. The amount of starch was only slightly lower than in the control. Even in the youngest leaves, mitochondria had a very dense matrix and dilated, electron-lucent cristae, similarly to the oldest control leaves. Similar to the oldest control leaves, the number of peroxisomes, and in particular the number of paracrystalline structures contained in them, significantly decreased. Nuclear chromatin, even in young leaves, was much stronger condensed than in the control old leaves (Figs 14, 15 - arrows).

\section{The influence of the $1.6 \mathrm{mg} / \mathrm{ml}$ concentration}

The afore-described changes in the leaf ultrastructure, resulting from the treatment of plants with the $0.4 \mathrm{mg} / \mathrm{ml}$ concentration of the extract, were even more intense after the treatment with a four times higher concentration $(1.6 \mathrm{mg} / \mathrm{ml})$.

The cytoplasm, even in young leaves, showed strong vesiculation (Figs 14, 19, 20), forming polyvesicular bodies (Figs 16, 18). Aggregations of degraded smooth ER membranes were also formed (Fig. 17). In older leaves, polyvesicular bodies, often in conglomerates with membrane-like structures, pressed the tonoplast and invaginated into the central vacuole (Figs 19, 20). Apart from such elastic structures, vesicles of different sizes (sometimes very large) were observed. They occurred in masses between the cytoplasm and the tonoplast and did not invaginate into the central vacuole (Fig. 19).

Simultaneously with the process of endocytic movement of membrane-like structures to the central vacuole, after treatment with the more concentrated extract, a large part of the small vesicles escaped through the plasmalemma outside the cells (Figs 18, 20 - arrowheads).

Starch almost completely disappeared from the chloroplasts, especially in the oldest leaves (Fig. 21), whereas plastoglobuli increased in size and number. They were particularly large in the spongy parenchyma (Figs 21, 22). The thylakoid system was further distorted. The regular structure of grana was rarely observed, and only in the youngest leaves (Figs 16, 18). At further stages, they underwent almost total disintegration (Figs 21, 22). Intergranal thylakoids lost their regular shape (Figs 21, 22) and became irregularly dilated even in the youngest leaves. Dilations increased along with aging. (Figs 15, 18, 21, 22 - arrows).

Nuclear chromatin was very strongly condensed and in the cells of the oldest leaves, it had a mosaic-like appearance, sharply contrasting with electron-lucent karyolymph (Fig. 22).

Figs 14-18. Ultrastructure of pepper leaves after treatment with the extract: at the concentration of $0.4 \mathrm{mg} / \mathrm{ml}-\mathrm{Figs} 14,15$. Ultrastructure of young pepper leaves treated with the extract at the concentration of $1.6 \mathrm{mg} / \mathrm{ml}$ - Figs. 16-18.

Fig. 14. A young leaf: cell nucleus with chromatin much stronger condensed than in the control (arrows) and electron-dense nucleolus. Plastoglobuli (pg) in chloroplasts are small, dark and scarce, similarly as in control young leaves. Mitochondrion (arrow head), similarly as in old control leaves (Fig. 13) has dense matrix and dilated cristae. Bar $=1 \mu \mathrm{m}$.

Fig. 15. An old leaf, a fragment of upper epidermis and palisade parenchyma: cytoplasm in cells appears as a thin layer adjacent to cell walls. Cell nucleus (N) with strongly condensed chromatin. Chloroplasts $(\mathrm{Ch})$ are deformed, flattened, with visible starch. The central vacuole contains scarce, small, irregular electron-dense deposits (d) and single large vesicles (v). Bar $=1 \mu \mathrm{m}$.

Fig. 16. A fragment of spongy parenchyma: cytoplasm filled with small vesicles. Most of them are within membraned bodies (mv). Dilatations of intergranal thylakoids - arrows. Plastoglobuli (pg) with lucent spots at the borders or in the middle. Mitochondrion with very dense matrix and dilated cristae. Under plasmalemma, vesicles expelled from the cytoplasm are visible (thin arrows). Bar $=1 \mu \mathrm{m}$.

Fig. 17. A fragment of palisade parenchyma. The cytoplasm contains membrane-like structures (ms) formed of smooth ER. Bar $=1 \mu \mathrm{m}$.

Fig. 18. A fragment of palisade parenchyma: dilated chloroplast thylakoids (arrows), mitochondria with dense matrix and dilated cristae; polyvesicular bodies (ms) within cytoplasm and in the vacuole; concentrations of small vesicles under plasmalemma (arrow heads). Bar $=1 \mu \mathrm{m}$. 

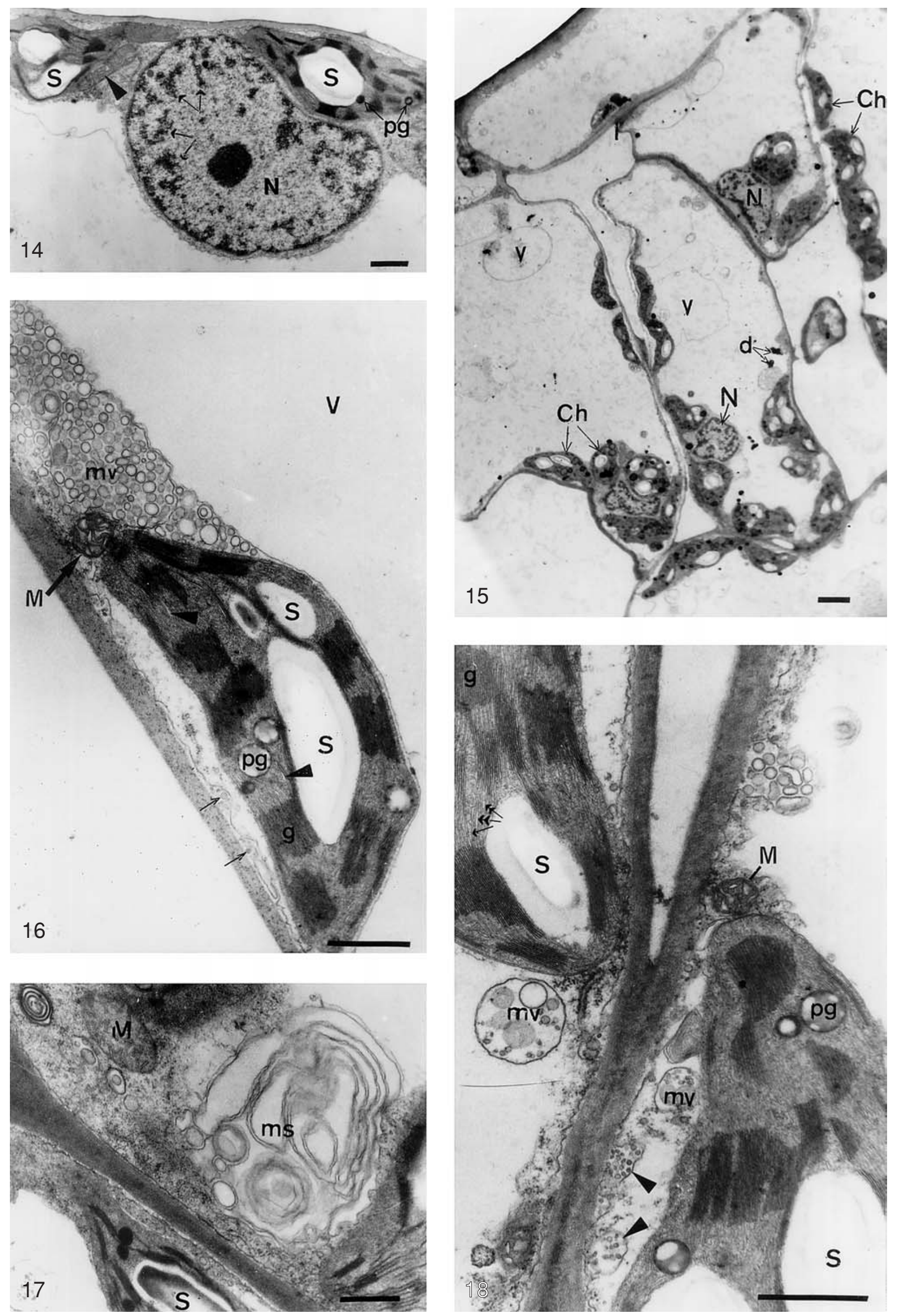
Mitochondria, just like in the case of the lower extract concentration, had a dense matrix and numerous cristae, which were electron-lucent (unlike in the control) and often oblong or dilated (like in old control leaves) (Figs 16, 18, 20, 21).

Similarly as in the case of treatment with the $0.4 \mathrm{mg} / \mathrm{ml}$ concentrated extract, no large spherical deposits in vacuoles were observed.

\section{DISCUSSION}

The idea of the above-described investigations is a result of world-wide interest in therapeutical effects of the Uncaria tomentosa extract. Choosing Capsicum as the test material, we wanted to gain information regarding changes to the growth and development processes resulting from prolonged influence of Uncaria tomentosa bark extract on the whole plant, which constitutes a certain analogy to the way of its action on human organism in therapeutic conditions.

The main purpose of our study was to determine the influence of the Uncaria tomentosa bark extract on the ultrastructure of Capsicum leaves. Results of these investigations showed both typical features during leaf ontogenesis in general and some properties specific only for that species. The analysis of mesophyll ultrastructure, even in young control leaves, indicated their strong metabolic activity. The presence of numerous typical peroxisomes beside active mitochondria and chloroplasts with a well-developed system of granal and intergranal thylakoids and numerous starch grains may indicate, among others, a high level of photorespiration of cells (Newcomb and Frederick 1971; Tolbert 1971), which was observed at that stage of plant development in pepper leaves (Schgwitzguebel and Siegenthaler 1984). In addition to those organelles, cytoplasm of mesophyll cells contains numerous multivesicular structures, moving towards the central vacuole, which contains large spherical osmophilic deposits. Modification of the ultrastructure, reflecting the metabolic activity of cells, is stronger in mature leaves. In addition to the aforementioned structures, now produced in greater amounts than before, mesophyll chloroplasts (only at this stage) contain very long paracrystalline bodies, and plastoglobuli (much larger and lucent than in young leaves) are being expelled outside the chloroplast envelope. Expulsion of plastoglobuli from active chloroplasts has been described for two varieties of pepper by Simpson and Lee (1976). They have suggested that the lipid material, originating from expelled plastoglobuli, may be the source of electron-dense deposits, typical of pepper, located in leaf vacuoles. They could be formed as a result of condensation of lipoidal precursor in a similar way as sporopolenins (Dickinson and Bell 1972). However, our observations indicate that this is unlikely, as osmo- philic spherical deposits were found there in large amounts as early as in young leaves, which can be seen in Figs 3, 5. Instead, expulsion of plastoglobuli from chloroplasts started only in mature leaves.

Expulsion of plastoglobuli continues until the end of ontogenesis. Throughout all that period, spherical deposits gather in vacuoles. Starting from the mature leaf stage, intensified vacuolation of the cytoplasm is observed, which is connected with the occurrence of various forms of vesicles and membranous structures. The development of the membrane system in the ground cytoplasm is very specific for pepper. We may distinguish between at least two forms of vesiculation and formation of vacuoles. One of them is the „multivesicular bodies”, which are probably rigid, thus pressing on the tonoplast and pushing it into the area of the vacuole. The other system of more flexible membranes would be located close to the tonoplast forming conglomerations of vesicles which remained separate, not fusing or rarely fusing with the vacuole. The affinity of such membranes was low, suggesting their different role in the cell.

Along with the afore-described phenomena, processes typical of ageing occur in the oldest examined leaves (Barton 1966; Tevini and Steinmuller 1985; Nii et al. 1988). They include changes in chloroplasts (increase in size of vacuoles and change in their color, dilatation of thylakoids, lower amount of starch), condensation of nuclear chromatin, condensation of mitochondrial matrix.

The afore-mentioned changes in the ultrastructure, indicating high metabolic activity of the mesophyll cells, beginning in young leaves and increasing during their maturation, are probably connected with biosynthesis of various substances typical of pepper (Kohlmunzer 1998; Somos 1984). These are mainly capsaicin and its homologues, capsaicinoids - phenolic compounds of an alkaloid nature. Capsaicin forms colorless crystals of hot taste, which dissolve, among others, in acetone, ether or benzol. Capsaicin is the most abundant in placenta of pepper fruits. It is deposited in a complex with lipids, in spheroid receptacles, covered only with the cuticle (Ohta 1962). So far, no research into the deposition of capsaicinoids has been carried out. It is possible that they are deposited and stored in vesicles and vacuoles of different sizes due to their biological activity, similarly to anthocyanidins (Hrazdina et al. 1987) or protoanthocyanidins (Stafford 1987). Other compounds typical of pepper are numerous carothenoid dyes (capsanthin, capsorubin, cryptoxanthin, zeaxanthin, etc.). The concentration of those dyes might be related to the process of expulsion of plastoglobuli, which we observed. It has been long known that plastoglobuli are the site of deposition of estrified carothenoids (Lichtehnthaler 1969). Also Tevini and Steinmuller (1985) have reported on an increased level of estrified carothenoids in plastoglobuli of ageing beech leaves. We might as well speculate that some lipid soluble

Figs 19-22. Ultrastructure of old leaves - the effect of treatment with the extract at the concentration of $1.6 \mathrm{mg} / \mathrm{ml} . \mathrm{Bars}=1 \mathrm{\mu m}$.

Fig. 19. A fragment of palisade parenchyma: large electron-lucent vesicles (v) in the upper cell just above plasmalemma; polyvesicular structures (mv) invaginating into the central vacuole of the bottom cell; $\mathrm{M}$ mitochondrion, $\mathrm{t}$ tonoplast.

Fig. 20. A fragment of spongy parenchyma: a conglomeration of polyvesicular (mv) and membrane-like (ms) structures and single vesicles (v) invaginating into the central vacuole; cytoplasm with strongly flattened chloroplast (Ch), containing no starch and a very large plastoglobule (pg).

Fig. 21. A fragment of palisade parenchyma: chloroplast undergoing destruction, containing numerous large grey plastoglobuli (pg), degraded grana and dilated thylakoids (arrows).

Fig. 22. A fragment of palisade parenchyma: cell nucleus (N) with nucleolus $(\mathrm{Nu})$ of granular structure, extremely condensed chromatin (arrow heads) and electron-lucent karyolymph; chloroplast - as in Fig. 21, with a single starch grain (S). 

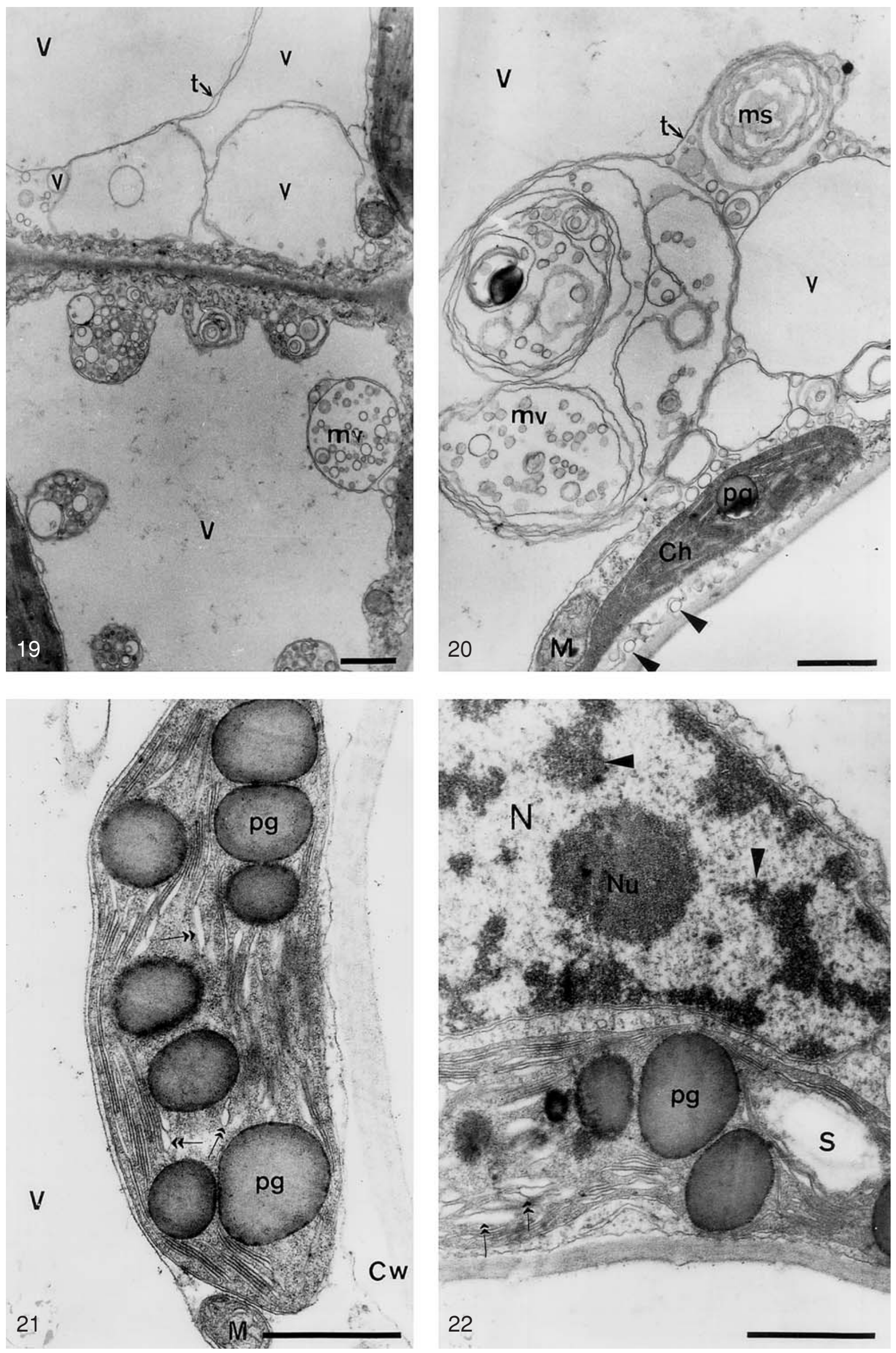
compounds were deposited in plastoglobuli, which caused their budding out and further expulsion to the cytoplasm or even to the vacuole, as we saw in older leaves. On the other hand, the presence of paracrystalline structures in chloroplasts of mature leaves might probably be correlated with the deposition of capsidiol. Polian et al. (1997) have found that such structures appear in chloroplasts of pepper leaves under treatment with capsidiol (sesquiterpene phytoalexin), obtained from pepper fruits and after infection of pepper with Phytophora capsici, when the host cells synthesise that substance.

Under treatment with Uncaria root extracts, the ultrastructural organisation of cells changes. The process of leaf ontogenesis is accelerated. Extremely large plastoglobuli, dilatation of thylakoids and strong condensation of nuclear chromatin that occur are also typical characteristics of naturally ageing control leaves of pepper and other plants (Dodge 1970; Inada 1999; Simeonowa et al. 2000). However, their very early occurrence (in the youngest leaves) and their intensity are different than in control leaves, indicating that the extract of Uncaria root accelerates and enhances the ageing processes.

Simultaneously, under treatment with the extracts, ultrastructural characteristics connected with the change in phytochemistry of cells occur, which proves the strong effect of $U$. tomentosa extract. For instance, we discovered a lack of opalescence in light microscope crystal structures, similar to those described by Somos (1984). Another change was the absence of spherical osmophilic deposits in vacuoles, lack of paracrystalline structures in chloroplasts and no expulsion of plastoglobuli from chloroplasts, which proves the strong effect of $U$. tomentosa extract. More experiments are necessary in order to determine which biosynthetic pathways are changed by $U$. tomentosa activity.

The above-presented results of our investigations constitute a sequence of ontogenetic ultrastructural changes of pepper leaves on the one hand, and their changes induced by prolonged treatment with $U$. tomentosa bark extract on the other. In the first case, in control leaves, we deal with intensive achievement of the developmental optimum and the phase of maturity, and subsequent inhibition of metabolic activity, leading to the phase of programmed cell death. It is based on DNA fragmentation (Simeonowa et al. 2000), correlated with ultrastructural rearrangement of all cellular organelles and physiological inactivation of growth and development. Although our research was limited to the analysis of the ultrastructural organisation of leaves, its analogy to the correlation of ultrastructural changes with the induction of apoptosis, as reported by Simeonowa et al. (2000), suggests that such phenomenon also takes place in the cells of pepper leaves. Thus, the degradation of ultrastructure observed in old control pepper leaves is also induced by the achievement of the phase of their programmed cell death by the cell. In the second case, after the treatment with $U$. tomentosa bark extracts, we deal with obvious acceleration of the ontogenetic development of pepper leaves, which also implies acceleration of processes of selectively induced, programmed cell death (ageing) and enhancement of its phenotypic and ultrastructural effects. Thus, if pepper cells entered the phase of accelerated apoptosis already in young leaves, it means that the treatment caused an earlier onset (like in human leukaemic lines HL60, Sheng et al. 1998) of the main mechanism of the apoptosis program. By using electrophoresis in their investigations, these authors found that, through DNA fragmentation, U. tomentosa bark extract inhibited the natural metabolic processes of human leukaemic line cells and human lymphoma cells, selectively inducing their apoptosis. Thus, the first reported suggestions for the anti-tumor activity of $U$. tomentosa extract in HL-60 cells seem to be supported by our experiment on pepper leaves. It leads to the assumption that the same mechanism takes place in Capsicum leaf cells. If the specific activity of $U$. tomentosa bark extract, discovered in our experiments, is confirmed with other cell systems, and in particular on other human cancer lines, it is likely to be used (in synergy with other drugs) in the anti-cancer therapy. Thus, we hereby postulate that the continuation of works on $U$. tomentosa extract preparations, their properties and mechanisms of action, combined with other biological tests, is absolutely recommended.

\section{ACKNOWLEDGEMENTS}

This research was partially supported by the „A-Z” Medica Sp. z o.o. Sopot (order no 01; 09.10.2001).

\section{LITERATURE CITED}

AQUINO R., DE TOMMASI N., DE SIMONE F., PIZZA C. 1997. Triterpenes and quinovic acids glycosides from Uncaria tomentosa. Phytoc. Hem. 45: 1035-1040.

BARTON R. 1966. Fine structure of mesophyl cells in senescing leaves of Phaseolus, Planta 71: 314-325.

BEDNAREK D., ŁUKASIAK J., KONDRACKI M., ŻUROWSKA K., FALKIEWICZ B. Immunomodulating effect of Uncaria tomentosa in claves. Med. Sci. Monitor (in press).

DODGE J.D. 1970. Changes in chloroplast fine structure during the autumnal senescence of Betula leaves. Ann. Bot. 34: 817$-824$.

GULEWICZ K., TYKARSKA T., WYSOCKI W., AUGUSTYNOWICZ J., ŻUROWSKA K., KURAŚ M. Developmental and ultrastructural effect of Uncaria tomentosa L. extract on the paprica Capsicum annuum L. Ind. Crops and Products (in press).

HRAZDINA G., ZOBEL A.M., HOCH H.C. 1987. Biochemical, immunological and immunochemical evidence for the association of chalkone synthase with endoplasmic reticulum membranes. Proc. Nat. Acad. Sci. U.S.A. 84: 8966-8970.

INADA N., SAKAI A., KUROIWA H., KUROIWA T. 1999. Senscence program in rice (Oryza sativa L.) leaves: analysis of the blade of the second leaf at the tissue and cellular leaves. Protoplasma 207: 222-232.

KEPLINGER K. 1982. Cytostatic, contraceptiwe and antiinflammatory agents from Uncaria tomentosa. PTC Int. Appl., WO 8201,130

KEPLINGER K., LAUS G., WURM M., DIERICH M.P. 1999. Tepner H. Uncaria tomentosa (Wild). DC - etnomedicinal use and new pharmacological, toxicological and botanical results. J. Ethnopharmacol. 64: 23-34.

KOHLMUNZER S., Farmakognozja. Wyd. V. Wydawnictwo Lekarskie PZWL, Warszawa 1998.

LAUS G., BROSSNER D., KEPLINGER K. 1997. Alkaloids of Peruvian Uncaria tomentosa. Phytochemistry 45: 855-860.

LEVAN A. 1938. The effect of colchicine on root mitoses in $\mathrm{Al}$ lium. Hereditas 24: 471-486.

LICHTENTHALER H.K. 1969. Zur Synthese der lipophilen Plastidenchinone und Sekundärcarotinoide während der Chromoplastenen-twicklung. Ber Dtsch Bot. Ges. 82: 483-497. 
MONTENEGRO DE MATTA S., DELLE MONACHE F., FERRARI F., MARINI-BETTOLO G.B. 1976 Alkaloids and procyanidins of an Uncaria sp. from Peru. Farmaco Sci. 31: 527-535.

NEWCOMB E.H., FREDERICK S.E. 1971. Distribution and structure of plant microbodies (peroxisomes). In: Photosyntesis and photorespiration. Hatch M.D., Osmond C.B., Slater R.O. Wiley-interscience, a Division of John Wiley\&Sons, Inc. New York. pp 442-457.

NII N., KAWANO S., NAKAMURA S. 1988. Changes in the fine structure of chloroplast and chloroplast DNA of Peach leaves during senescence. J. Japan. Soc. Hort. Sci. 57: 390-398.

OHTA Y. 1962. Physiological and genetical studies on the pungency of Capsicum species. Jap. J. Genet. 37: 86.

POLIAN C., COULOMB P.J., LIZZI Y., COULOMB C. 1997. Altération du systčme membranaire de protoplastes de feuilles de piment (Capsicum annuum) sous I'action du capsidiol. Life Sci. 320: 721-727.

REYNOLDS E.S. 1963. The use of lead citrate at high $\mathrm{pH}$ as electron-opaque stain for electron microscopy. J. Cell. Biol. 17: 208-213.

SALAZAR E.L., JAYME V. 1998. Depletion of specific bildingsites for estrogen receptor by Uncaria tomentosa. Proc. West Pharmacol. Soc. 41: 123-124.

SANDOVAL-CHACON M., CHARBONNET R.M., OKUHAMA N.N., ROBERTS J., KRENOVA Z., TRENTACOSTI A.M., MILLER M.J. 2000. Cat's claw inhibits TNF $\alpha$ production and scavenges free radicals: role in cytoprotection. Free Radic. Biol. Med. 29: 71-78.

SANDOVAL-CHACON M., THOMPSON J.H., ZHANG X.J., LIU X., MANNICK E.E., SADOWSKA-KROWICKA H., CHRBONNET R.M., CLARK D.A., MILLER M.J. 1998. Antiinflammatory actions of cat's claw: the role of NF- $\kappa B$. Aliment. Pharmacol. Ther. 12: 1279-1289.
SCHWITZGUEBEL J.-P., SIEGENTHALER P.-A. 1984. Purification of peroxisomes and mitochondria from spinach laef by gradient centrifugation. Plant Physiol. 75: 670-674.

SENATORE A., CATALDO A., IACCARINO F.P., ELBERTI M.G. 1989, Ricerche fitochimische e biologische sull' Uncaria tomentosa. Boll. Soc. Ital. Biol. Sper. 65: 517-520.

SHENG Y., BRYNGELSSON C., PERO R.W. 2000. Enhanced DNA repair, immune function and reduced toxicity of CMED.-100TM, a nowelaqueous extract from Uncaria tomento$s a$. J. Ethnopharmacol. 69: 115-126.

SHENG Y., PERO R.W., AMIRI A., BRYNGELSSON C. 1998. Induction of apoptosis and inhibition of proliferation in human tumor cells treated with exstracts of Uncaria tomentosa. Anticancer Res. 18: 3363-3368.

SIMEONOVA E., SIKORA A., CHARZYŃSKA M., MOSTOWSKA A. 2000, Aspects of programmed cell death during leaf senescence of mono- and dicotyledonous plant. Protoplasma 214: 93-101.

SIMPSON D.J., LEE T.H. 1976. Plastoglobules of leaf chloroplasts of two cultivars of Capsicum annuum. Cytobios 15: 139$-147$.

SOMOS A. 1984. De paprika. Akademiai Kiado, Budapest.

STAFFORD H.A. 1987. Enzymology of proanthocyanidin biosinthesis. In: Hemingway R.W., Karchesy J.J. (eds). Cemistry and Significance of condensed tannins. New York. Plenum: 47-70.

TEVINI M., STEINMULLER D. 1985. Composition and function of plastoglobuli. Planta 163: 91-96.

TOLBERT N.E. 1971. Leaf peroxisomes and photorespiration. In: Photosyntesis and photorespiration. Hatch M.D., Osmond C.B., Slater R.O. Wiley-interscience, a Division of John Wiley\&Sons, Inc. New York: 458-471.

\title{
BADANIA STRUKTURY I ULTRASTRUKTURY LIŚCI CAPSICUM ANNUUM TRAKTOWANYCH EKSTRAKTEM Z KORY UNCARIA TOMENTOSA
}

\author{
STRESZCZENIE
}

Badano wpływ ekstraktu z kory Uncaria tomentosa na wzrost i rozwój roślin papryki w warunkach szklarniowych. Efekty traktowania ekstraktem otrzymano przy użyciu techik mikroskopowych (mikroskop świetlny i elektronowy) w liściach z trzech poziomów roślin kontrolnych i roślin jednorazowo podlanych ekstraktem (200 ml na doniczkę) o koncentracjach 0,4 i $1,6 \mathrm{mg} / \mathrm{ml}$.

W liściach kontrolnych obserwowano zmiany typowe dla kolejnych faz rozwoju takie jak: lekka kondensacja chromatyny jądrowej, wzrost ilości i wielkości plastoglobul oraz niewielką dylatację tylakoidów międzygranowych. Jednocześnie oprócz tych zmian w ontogenezie liści papryki obserwowano przejawy charakterystyczne tylko dla tej rośliny: wzrost liczby dużych, elekronowo-gęstych depozytów w wakuolach, przejściowy wzrost perokzyzomów, częste występowanie struktur parakrystalicznych w chloroplastach dojrzałych liści i wypadanie plastoglobul z chloroplastów dojrzałych liści.

Po traktowaniu ekstraktem większość tych zmian pojawiła się we wcześniej fazie rozwoju liści i były one bardziej nasilone. Chloroplasty już w młodych liściach wykazywały dylatację międzygranową tylakoidów, wzrastająca w miarę starzenia się liści, oraz degradację gran w najstarszych liściach. Chloroplasty zawierały większa liczbę powiększonych plastoglobul a ziarna skrobi ulegały zmniejszeniu. Wakuolizacja podstawowej cytoplazmy w starszych liściach była silniejsza niż w kontroli. Nie obserwowano parakrystalicznych struktur w chloroplastach ani wypadania plastoglobul. Innym zjawiskiem było zanikanie typowych dla kontroli sferycznych elektronowo-gęstych złogów w centralnej wakuoli komórek papryki.

Te obserwacje sugerują, że ekstrakt z U. tomentosa wzmaga naturalną ontogenezę liści Capsicum poprzez przyspieszenie i nasilenie zmian w strukturze i fizjologii komórek, charakterystycznych dla starzenia się.

SŁOWA KLUCZOWE: Liście Capsicum, ekstrakt z Uncaria tomentosa, działanie cytostatyczne, ultrastruktura. 